2. Ворона Н. О., Пилипенко-Фріцак Н. А. Українські паремії 3 соматичними компонентами. Вісник Маріупольського державного університету. Філологія. Маріуполь, 2020. Вип. 22. С. 113-121.

3. Красных В.В. Коды и эталоны культуры (приглашение к разговору). Язык, сознание, коммуникация: сб. статей / отв. ред. В. В. Красных, А. И. Изотов. Москва, 2001. Вып. 19. С. 5-19.

4. Маслова В. А., Пименова М. В. Коды лингвокультуры. Москва : Флинта, 2016. 180 c.

5. Шарманова Н. М. Коди культури та їх репрезентація в усталених словесних комплексах. Філологічні студї. Науковий вісник Криворізького державного педагогічного університету. Кривий Ріг, 2013. Вип. 9(2). С. 194-204.

6. Alexander A. Shestakov. Cultural code concept in contemporary world. Department of Public Administration and Organizational Theory Bergen University. Spring - 2008. 103 p.

7. Valentine S. Lee, Ainakul B. Tumanova and Zhanat H. Salkhanova. New Approaches to a Subject of Anthropocentric Linguistics. International journal of environmental \& Science education. 2016. Vol. 11, No. 11. P. 4716-4728.

DOI https://doi.org/10.30525/978-9934-26-073-5-1-3

\title{
СЛОВОТВОРЧІ Й ФОРМОТВОРЧІ ЧАСТКИ В ДРАМІ ЛЕСІ УКРАЇНКИ «РУФІН І ПРІСЦІЛЛА»
}

\author{
Гандзюк О. М. \\ кандидат філологічних наук, \\ доиент кафедри української мови \\ Волинського національного університету імені Лесі Українки \\ м. Луцььк, Украӥна
}

Частка - «це службова частина мови, яка надає слову чи реченню додаткового відтінку або слугує засобом творення слів та похідних слів». За роллю у слові та реченні частки поділяються на 1) формотворчі, 2) словотворчі, 3) фразові (заперечні та модальні) [1, с. 311].

У названій драмі Лесі Українки широко вжиті словотворчі й формотворчі частки. Аналіз цих типів часток здійснюємо на матеріалі твору «Руфін і Прісцілла», опублікованому в другому томі драматичних творів в двох томах (К.: Наукова думка, 1987.726 с.). 
Ті види часток, які здійснюють реалізацію словотворчої функції, завжди поєднанні з іншими словами. «Новоутворені слова є складними за своєю будовою і переважно мають значення, відмінне від семантики непохідного слова.

В українській мові із словотворчою роллю виступають частки будь-, небудь, казна-, хтозна-, -сь, аби-, де-, не-, ні-, -би, б-, -же, -ж та ін.» $[2$, c. 510$]$.

У тканині втору вжиті такі словотворчі частки:

-таки: Руфін. Тут уже немає і того талану, що в листах Павла усетаки просвічує нелад (с. 13);

-ся: Парвус. Зостанься з богом, сестро! (с. 20); Руфін. Я б за щзастя вважав, якби ти в мене оселився ( с. 22); Кай Летіцій. Я дивую, чому в тобі не відродився Брут аж до кіния...(с. 28); Руфін. Ти так впевняєшся на ті закони? (с. 30); Панса. Не гнівайся, добродію (с. 127); Панса. Та от ніяк не допрошуся згоди (с. 126);

сь- : Парвус. Не може помиритись вода з олією (с. 17); Руфін. Від нього ліків я не знаю, правда, але миритись не здолаю! (с. 29); Кай Летіцій. Ся віра зародилась в Палестині (с. 31); Чи зопалу ти слово се сказала, чи привід маєш щось такого думать? (с. 37); Руфін. Де не буває, щзо трапиться дитині заблукатись? (с. 39); Круста. Ага, до речі, я зустрів Прісиіллу на вулиці, кудись так посіпішала, що я не встиг $i$ привітатись гідно (с. 58);

де-: Панса. Десь, кажеш, ми зустрінемось, то як же ти глянеш в очі батькові старому, що згинув від одчаю через тебе? (с. 128);

-то: Прісцілла. Нехай тяжка й трудна мандрівка наша, але ж вона не так-то ще і давня, щоб думати про край $і$ береги (с. 17); Руфін. Такіто «добрі римські громадяни» колись нам Рим до згуби доведуть! (с. 25); Аецій Панса Отож-то я й кажу! (с. 27);

-небудь : Прісцілла. У кого-небудь в хаті (с. 52).

У драмі багато випадків вживання слів, які без частки не- не використовуються. Це слова таких частин мови, як:

іменник: Аецій Панса. Не подоба громадської роботи оминати, ще хто готовий поговір пустити, неначе ти вступив до тої секти, що млявість прищепляє та байдужіть, недбайність про державу і громаду (c. 23); Аецій Панса. Ба! А все ж пішла, он кажуть, в християни, як хоч, се ж для матрони неподоба (с. 32); Руфін. Я б не просив тебе покинуть віру, лише не виставлятися прилюдно, не наражатися на небезпечність (с. 45); Руфін. Приємна несподіванка! (с. 62);

прикметник: Руфін. Чи тим, щуо він з свойм коханим другом, нікчемним Крустою, наводить жах на всіх погрозою свойх доносів? 
(с. 26); Руфін. Хоч і дивлюся з невимовним болем, як гине Рим... (с. 29); Руфін. «Пусти мене, бо ти мені бридкий, ненавидний моїй душі і серцюю» (с. 43);

прислівник: Руфін. У тебе це парується так легко, а в мене сі слова ідуть урозтіч і ставляться, як два мечі на гериі, одно напроти одного так гостро, непримиренно... ( с. 27); Незабаром другий раб виносить кухоль пива і три фіали (с. 58);

дієслово: Руфін. Старий недочуває (с. 62).

Частка не відіграє роль префікса в іменниках, прикметниках i прислівниках, 3 іiі допомогою утворюються антоніми до відповідних безпрефіксних слів [2, с. 511].

Зокрема, в іменниках частка формує такі значення:

брехня: Неправди я казать тобі не хочу, а правду перемовчать не здолаю: так, я була сьогодні в катакомбах $і$ завтра знов піду, як тільки ти мені того не заборониш (с. 7); рабство: Руфін. Я тебе пустив би, я б не держав тебе в неволі в себе, якби ти раз мені сказала в вічі...(с. 43); трудність: Диякон. Я гадаю, сину, щуо й ию справу зважить нам несила (с. 72); лицемірство: Диякон. Ти стережися так кидати словами, зневірся $і$ нещцирість посівати в громаді нашій братній (с. 73); ризик: Руфін. Чи се так важно, щуо для того варто на небезпеку наражатись? (с. 77); малятко: Люцій. Посеред дороги він мало-мало не звернув на бенкет знов до Летіція, та я завів його до хати, і поклав на ліжко, та ще й приспав, як мати немовлятко (с. 78).

У прикметниках ця частка уможливлює значення:

страшна: Аецій Панса. О, коли так, се небезпечна секта, бо ми ж не знаєм, хто з них єретик, а хто сектяр звичайний (с. 34); маленьке: Круста. Се він і Діоніса переважив, коли не брешуть люди: з винограду вино зробити - невелике чудо, ні, ти зроби його з води! (с. 68); близький (за часом): Круста. От я знаю сам таких, щзо цеззаря готові зневажати для них він, бач, тиран та узурпатор - самі ж при тому за гостей приймають усяких відпущеників, недавніх рабів, чужинців варварської крові, усяку темношкіру покруч (с. 67);

підозрілий: Парвус. Що ж, ніде правди діти, воно й мені теж видалось непевним (с. 73); брудний: Кай Летіцій. Сабіну ту засуджено за зв 'язок нечистий з рідним братом (с. 32); підозріла: Прісцілла. $\mathrm{Hi}$, се непевна річ (с. 53);

В прислівниках утворюються значення:

мало: Прісцілла. У Римі небагато чоловіків таких, як ти, а може, ти єдиний на иілий Рим (с.7); щойно: Кай Летіцій. На тортурах засвідкував недавно раб один, щзо в християн підслухав під дверима він сам слова 
такі... (с. 33); погано: Круста. Мій бідний друже, як тобі недобре! (c. 56); ніяк: Прісцілла. Hi, нi, се неможливо (с. 52); визначено: Руфін. От $і$ Круста недарма про жінок так говорив, коли прийшов, зустрівиися з тобою (с. 66).

Заперечні займенники творяться 3 використанням словотворчої частки ні: ніхто: Прісцілла. Таж ти не поклоняєшся віддавна нікому 3 тих богів, щңо в пантеоні (с. 17); ніякий: Прісцілла. Він справді ні холодний, ані теплий, як дерево сухий, зовсім ніякий (с. 14) ; Руфін. Прісцілло! Дружино мого серия... я не можу ніяким словом вимовити страху, тривоги тої злої, що, мов яструб, кривавить, мучить, роздирає серие за кожним разом, як ти там буваєи (с. 8); Руфін. Сказати правду, я не бачу дива ніякого в настанні Павла з Савла (с. 9); ніщо: Прісцілла. Як ти непевний, то й мені не вір, - нічого я не крию від Руфіна (с. 8).

3 цією ж часткою творяться й заперечні прислівники: ніколи: Аецій Панса. Загинути не може Рим ніколи (с. 25); ніяк: Руфін. А. Я забув!.. ніяк не можу звикнуть, що ти ж мене зовсім вже не кохаєш!.. (с. 44).

В утворенні порівняльних сполучників бере участь частка не: немов: Руфін. Адже в його листах, у кожнім слові, загонисту вояцьку вдачу видно: він словом бив, немов вояк мечем, дарма щчо про любов умів балакать (с. 11); неначебто: Прісцілла. Засуджено недавно християнку, неначебто за чари, до спаління, а чоловік ї̈ зоставсь безпечний (с. 42).

Формотворчі частки сприяють утворенню наказового способу дієслова для 3 особи однини та множини, напр.:

3 особа однини: Прісцілла. Може, се й гординя, - нехай Господь простить мені за неї! ...(с. 8);

3 особа множини: Руфін. Нехай вони ввіходять не через браму. А в садову хвіртку з малої вулиці (с. 53); Кай Летіцій. Нехай боги не чують сього слова! (с. 25).

Вони ж беруть участь в утворенні умовного способу дієслова 3 застосуванням часток б (би), напр.: б: Кай Летіцій. Певне, мірка всіх римських цинот побільщала б ізнову, якби такий зразок було їй дано (с. 26); Прісцілла. Що б ти сказав, якби почув від мене подібне слово в ті часи, як ти збирався воювать за славу Риму? (с. 40); би: Кай Летіцій. $\mathrm{Hi}$, я одно хотів би знать, Руфіне, чи довго ти збираєшся носити оцю жалобу духу самовільну? (с. 30); Руфін. Сказав би, що негідно се матрони, дочки і жінки римських громадян (с. 40); Руфін. Ти гість мені сьогодні - образити тебе я не хотів би (с. 79).

3 допомогою цього виду частко твориться найвищий ступінь порівняння прикметників : Руфін. Нi, вже я волію державу навіть цезарів найгіриих, - хоч я республіканець, як ти знаєш (с. 13); 
Кай Летіцій. Твоя дочка й найбільшої достойна (с. 27) і прислівників: Фортунат. Авжеж, найкраще так, нехай єпископ (с. 71); Прісцілла. По чім же признають найбільще нас? (с. 46); Прісцілла. Таж єпископ найдальше мешкає (с. 53); Аецій Панса. Найкраще так, побачити на очі, тоді ніяким брехням не повіриш ( (с. 21); Сервілія. Там був один... старий вже дідуган, так той найбільие вабив (с.37).

Як показують приклади, в драмі Лесі Українки «Руфін і Прісцілла» функціонує багато словотворчих та формотворчих часток. Словотворчі частки беруть участь в утворенні певних груп слів, формотворчі частки допомагають творити наказовий, умовний спосіб дієслова, найвищий ступінь порівняння прикметників та прислівників. Дослідження типів часток можна продовжити, аналізуючи інші драматичні твори письменниці.

\title{
Література:
}

1. Плющ М.Я. Граматика української мови. Морфеміка. Словотвір. Морфологія: підручник. К. : Видавничий Дім «Слово», 2010. 2-е видання, доповнене. $328 \mathrm{c}$.

2. Сучасна українська літературна мова. Морфологія / за заг. ред. І.К. Білодіда. К. : Наук. думка, 1969. 583 с.

DOI https://doi.org/10.30525/978-9934-26-073-5-1-4

\section{ГЛЮТОНІЙНІ ПАРЕМІЇ ЯК ЗГУСТКИ ЛІНГВОКУЛЬТУРНОЇ ІНФОРМАЦІЇ НАЦІОНАЛЬНОЇ СПІЛЬНОТИ}

\author{
Колоїз Ж. В. \\ доктор філологічних наук, професор, \\ завідувач кафедри украӥнської мови \\ Криворізького державного педагогічного університету \\ Масляєва I. В. \\ здобувач вищої освіти PhD 035 Філологія \\ Криворізького державного педагогічного університету \\ м. Кривий Ріг, Дніпропетровська область, Украӥна
}

Питання про те, як відбувається вербалізація культури, не нове. Мовознавці різних часів і народів у той чи той спосіб досліджують специфіку втілення в мовні форми елементів матеріальної й духовної 